\title{
Legitimacy Gaps in the World Economy: Explaining the Sources of the IMF's Legitimacy Crisis $^{1}$
}

\author{
Leonard Seabrooke ${ }^{\mathrm{a}, \mathrm{b}}$ \\ ${ }^{a}$ International Center for Business and Politics, Copenhagen Business School, Steen Blichers Vej \\ 22, Frederiksberg 2000, Denmark. \\ E-mail: 1s.cbp@cbs.dk \\ ${ }^{\mathrm{b}}$ Department of International Relations, Research School of Pacific and Asian Studies, The \\ Australian National University, ACT 0200, Australia. \\ E-mail: Leonard.seabrooke@anu.edu.au
}

Since the Asian financial crisis of 1997-1998, the International Monetary Fund (the Fund) has been embroiled in an international crisis of legitimacy. Assertions of a crisis are premised on the notions that the Fund's voting system is unfair, that the Fund enforces homogeneous policies onto borrowing member states and that loan programmes tend to fail. Seen this way, poor institutional and policy design has led to a loss of legitimacy. But institutionalised inequalities or policy failure is not in itself sufficient to constitute an international crisis of legitimacy. This article provides a conceptually-driven discussion of the sources of the Fund's international crisis of legitimacy by investigating how its formal 'foreground' institutional relations with its member states have become strained, and how informal 'background' political and economic relationships are expanding in a way that the Fund will find difficult to re-legitimate. The difference between the Fund's claims to legitimacy and how its member states, especially borrowers, act has led to the creation of a 'legitimacy gap' that is difficult to close. However, identifying the sources of the Fund's international crisis of legitimacy allows us to explore what avenues are available to resolve the crisis.

International Politics (2007) 44, 250-268. doi:10.1057/palgrave.ip.8800187

Keywords: International Monetary Fund; legitimacy crisis; legitimacy gap; financial crisis; conditionality; deliberation; associational template

\section{Introduction}

The International Monetary Fund (IMF) (the Fund) acknowledges that it currently has an international crisis of legitimacy. Rodrigo de Rato, the Fund's Managing Director, has publicly stated that the IMF's legitimacy is suffering from a combination of formal institutional constraints and, more broadly, from how its policies are perceived by international and world society. Institutionally, the Fund is criticised for a voting system that heavily favours 
Western states, and especially the US. Operationally, the Fund's success rate in reforming borrowing member states is hardly exemplary. Its attempts to expand its policy area to include 'softer' social issues, such as social development programmes, have been met with external suspicion and internal fighting over what exactly the Fund's purpose should be (Vetterlein, 2006a). Within policy and scholarly circles, the Fund is heavily criticised for imposing excessively homogeneous policies on borrowing states; a homogeneity that is tantamount to a new 'standard of civilisation' that reflects the dictates of a 'Wall Street-Treasury-IMF Complex' (Wade and Veneroso, 1998; Best, 2006).

Within this Special Issue, an international crisis of legitimacy is defined as a 'critical turning point when decline in an actor's or institution's legitimacy forces adaptation (through re-legitimation or material inducement) or disempowerment' (Reus-Smit, this volume). If we look for a moment in which the Fund's international crisis of legitimacy can be pinpointed, then we would be hard pressed to look beyond the Asian financial crisis of 1997-1998. The Fund, as its own independent policy review arm has stated (Independent Evaluation Office, 2003b), did misdiagnose the crisis and recommended policy reforms inappropriate for states facing a liquidity problem, rather than an export earnings problem (the difference between a current account and a capital account crisis). Furthermore, since the late 1990s the Fund has been reviewing the appropriateness of its own reform programmes, particularly the need to address social issues (see also Thirkell-White, 2004; Vetterlein, 2006a, 137). The Fund's recent acknowledgement of its need to address its legitimacy problems (de Rato, 2006, 131-132, and discussed below) confirms that the perception of an international crisis of legitimacy is shared not only by the Fund's member states, non-governmental organisations (NGOs), and other groups in world civil society, but also by the Fund. As I discuss below, this is a crisis that the Fund now seeks to resolve through formal institutional reforms and an informal expansion of its social constituency of legitimation.

Most of the literature criticising the Fund focuses on policy homogeneity, more commonly described as a 'one-size-fits-all' approach to economic policy reform. Increasingly in the last decade, the Fund has produced starkly similar policies for different economies on the grounds that one of its key functions, beyond surveillance (see Broome and Seabrooke, 2006), is to create 'world's best practice' in economic policy. There are good formal legitimacy and efficiency reasons to consider why the Fund should treat different states in a similar fashion. More importantly, however, alongside the Fund's stress on its capacity to provide 'world's best practice' economic advice, is an emergent discourse that stresses the absence of 'political will' in borrowing member states to implement loan conditions (Bird, 2003, 94-95; Independent Evaluation Office, 2003a, 30). Rather than engaging politics head-on to solve what the Fund itself perceives as a political problem, the Fund is attempting to 
marry a new moralising discourse with technocratic expertise (Best, 2005). Such an attitude does not foster deliberation with a common language that both borrowing member states and the Fund can agree.

This article assesses longer-term trends in how the Fund has lost legitimacy with its member states, especially borrowing member states, and how the Fund can resolve its current crisis. I seek to understand the source of the Fund's current international crisis of legitimacy by pulling apart the formal 'foreground' and informal 'background' aspects of the institutional and social relationship between the Fund and member states, especially borrowing member states. In doing so, I argue that the legitimacy of a system of power must be understood not only through the expression of beliefs, but also expressive practices (see also Seabrooke, 2007). I argue that we can understand the Fund's current crisis of international legitimacy through the growth of a 'legitimacy gap', understood as: the space between claims to the fairness and rightfulness of policy actions by those who seek to govern, and the conferral of legitimacy on these claims through belief-driven acts by those being governed (such as policy implementation). The content of a legitimacy gap has both 'foreground' and 'background' aspects, which I explicate below.

Closely linked to the idea of a legitimacy gap forming between claims made by the Fund and how its member states, and those people it has an impact upon, act is what I refer to as an associational 'template' for 'IMF Friendly' policy reforms (see also Broome and Seabrooke, 2006). Templates are how the Fund frames its claim to the legitimacy of proposed policy reforms. As such, templates are used to legitimate claims to policy reforms by presenting reforms as part universal (for all states, thereby treating all members as equals) and in part customised for an associational context (regional or like-grouping, thereby increasing the likelihood that a member state's government and/or population will view the reforms as appropriate for them). In the introduction to this Special Issue, Christian ReusSmit argues that an institution commands legitimacy to the extent that there is 'a generalised perception that its normative precepts are rightful'. In the case of the Fund, associational templates worked well because they provided a clear frame ('Asian', 'OECD', and so on) through which the Fund could make comparisons with like-groups to claim that reforms were appropriate. I suggest, drawing upon a larger study (Seabrooke, 2006d), ${ }^{2}$ that the use of associational templates within the Fund has declined, with greater stress being placed on universal 'world's best practice' policies. Such universal claims to legitimacy are hard to sustain because they have little traction in a domestic context. This has then led the Fund to resort to strategies centred on securing a state's 'ownership' of its reform policies, as well as the re-establishment of explicit global standards of conduct (Best, 2006; Bowden and Seabrooke, 2006).

The article proceeds as follows: (i) a discussion of the sources of the Fund's international crisis of legitimacy, outlining both 'foreground' and 'background' 
factors; (ii) the proposal of a 'legitimacy gap' between claims and conferrals on Fund reforms discussed alongside a conception of 'associational templates'; (iii) a discussion of how the Fund plans to address its international crisis of legitimacy; and (iv) a conclusion that explores how the Fund may best resolve its international crisis of legitimacy. Together, these sections seek to outline the Fund's international crisis of legitimacy (the problem), how legitimation works in practice (the process), and the means, correct or otherwise, for solving the problem (resolutions).

\section{Sources of the Fund's International Crisis of Legitimacy}

The Fund's current international crisis of legitimacy is primarily a consequence of how it relates to its member states, especially borrowing member states. Changes in the formal 'foreground' and more informal 'background' relations between the Fund and its member states have contributed to the Fund's international crisis of legitimacy (on foreground and background, see Campbell and Pedersen, 1996). Key here is a combination of formal institutional impediments alongside the broadening of its practices, informal agenda, and purpose. To use a narrow interpretation of Ian Clark's (2005) language on legitimacy in international society, the Fund now violates the principles that undergird its rightful membership and rightful conduct as an actor within international society, as well as the principles that allow the Fund to act as an arena for a society of states. Moreover, following Christian Reus-Smit's framework in the introductory essay to this Special Issue, the Fund has expanded its realm of political action and its social constituency for legitimation.

Pulling apart the 'foreground' and 'background' dimensions of how the Fund's relationship with its member states has changed provides a deeper understanding of its current problems. To do so, I offer four types of legitimation for the Fund in Table 1. In the foreground are the official institutionalised relationships between the Fund and its member states - the formal rules within a society of states. Here, the Fund's claims to legitimacy relate primarily to rightful membership, and the common retort from member states is to point to the role of power politicking in the Fund's decision-making

Table 1 Four types of legitimation for actors in international society

\begin{tabular}{lll}
\hline & Foreground & Background \\
\hline $\begin{array}{ll}\text { Claims } \\
\text { Acts }\end{array}$ & Rightful membership & $\begin{array}{l}\text { Social constituency of legitimation } \\
\text { Realm of political action }\end{array}$ \\
\hline
\end{tabular}


processes. Foreground legitimacy claims are also evaluated in relation to how the Fund acts within international society with regard to its member states, to the Fund's rightful conduct in performing its main duties of surveillance, lending, and economic reform programmes.

The background includes the more diffuse social impact of actions taken by the Fund. While the foreground is explicitly political in how the Fund relates to member states, the background includes the impact of Fund policies on economies and societies - which I view as political acts - as well as the creation of broader intersubjective understandings within which claims to legitimacy must ultimately be evaluated. Thus, while the foreground aspects are the formal design, procedures, and decision-making processes, the background represents the more 'everyday' ongoing relationships between those who implement Fund policies 'on the ground' and those the policies seeks to govern (Hobson and Seabrooke, 2007). Accordingly, the Fund's realm of political action is not only its rightful conduct with member states, but how the Fund acts in shaping what is politically and economically possible within states, including, of course, how Fund policies affect citizens within borrowing member states. As the Fund now operates in a range of economic and social policy areas not within the ambit of its original Articles of Agreement, its realm of political action clearly extends beyond what rightful conduct permits. The Fund's acts clearly reverberate through societies and generate attitudes that then have an impact on formal economic programme success. As such, the Fund's claims to legitimacy are made within a much broader context than its rightful membership permits. The Fund's view of its social constituency of legitimation has recently placed stress on 'political will' and 'ownership' within borrowing states' governments and, most recently (and discussed below), their populations (Boughton, 2003). Reus-Smit (this volume) argues that 'the question of which constituency an actor must establish legitimacy in can only be answered with reference to the political realm in which he or she seeks to act'. The Fund is now attempting to expand its social constituency of legitimation to meet with its increasing recognition of its realm of political action. I argue that it is doing so in ways that are wrongheaded. Importantly, for the Fund to resolve its international crisis of legitimacy, it must have all four types singing in unison. In general, the story here is that on both claims and acts, and foreground and background, these four aspects of the Fund's legitimation have become increasingly distanced from one another.

Most of the debate concerning the Fund's international crisis of legitimacy concentrates on the foreground aspects described above. A brief summary of the dominant arguments in the field will help us establish how we can identify a 'legitimacy gap', as well as how the Fund can address its background legitimacy problems. Within the work on the Fund, rightful membership and rightful conduct are typically conceptualised in two ways: that the Fund 
provides an institutional arena for a society of states, and that the Fund is an actor operating within a society of states. Scholars focus on how membership arrangements within the Fund, such as voting rights in the determination of Fund decisions, are weakening its legitimacy in international society. Similarly, on conduct, scholars focus on how the Fund's conduct in loan programmes, especially the determination of loan conditions, weakens its legitimacy as an actor within international society. I weave between both views of membership and conduct here, realising that this provides a spin on Clark's (2005) original conceptual framework.

On rightful membership a host of scholars point out how the Fund's institutional structure predisposes it to the whims of the international political economy's most powerful states, especially the US. A number of scholars have argued that a borrowing state's 'political proximity' to US national interest increases the likelihood of increased leniency on loan conditions (Thacker, 1999; Stone, 2002). Bessma Momani's (2004) work, for example, provides a clear demonstration of how US representatives on the Fund Executive Board have flexed their muscles to acquire 'softer' loan conditions for preferred allies. Much attention has been given to the determination of voting rights within the Fund, which formally reflect subscription quotas to Fund general resources. The key complaint here is that the Fund's rightful membership regulations provide the US with 17.1 per cent of the vote, while a 'special decision' within the Fund (such as approving an extraordinarily large loan for a state embroiled in a financial crisis) requires 85 per cent of votes. The US therefore has a clear veto, which it has used on a number of occasions due to US domestic political fights over the legitimacy of 'bailing-out' states in a financial crisis (Leaver and Seabrooke, 2000). The US, of course, also has allies. Rapkin and Strand (1997) argue that US voting power, if you include its direct allies, is actually 62.3 per cent. Unsurprisingly, the Fund is often criticised as a puppet for US interests.

Recent innovative work on the Fund reveals the extent to which member states cluster into groups to gain influence on Fund decision-making procedures. Within the Fund's Executive Board, the US, Japan, Germany, France, and the UK have their own representatives. China, Russia, and Saudi Arabia also have their own seat (Woods and Lombardi, 2006, 482). For the rest of the member states, clusters have formed around regional groups and like-states (Woods and Lombardi, 2006, 489). Such clustering reflects the extent of politicking within the Fund, and the extent to which Western states have an ongoing desire to influence its policies - despite the fact that no Western state has borrowed from the Fund since 1976. At present, the G7 states comprise 47 per cent of the votes within the Fund. If we look at the top 24 industrial states in the world economy then this figure increases to 60.3 per cent, while 22 emerging market states hold 20.4 per cent and the remaining 138 developing states 19.3 per cent of Fund votes (Truman, 2006, 528). The key 
consideration associated with voting rights within the Fund is not the influence on actual voting behaviour within the organisation, since actual voting is not common. Rather, as commented by Louis W. Pauly, voting rights strongly influence what is 'thinkable' within the Fund in terms of policy design and political considerations (1997, 113).

Debate over the Fund's formal rules of membership has suggested that despite sovereign equality among member states, the Fund has produced a new 'standard of civilisation' that implicitly ranks states (Hall, 2003; Best, 2006). The Fund's considerations on the distance between rightful membership and who should be considered part of its real constituency are related to how the Fund's practices have changed during the past 20 years. Here, rightful conduct is related to how the Fund treats its member states, while more informal changes have expanded the Fund's realm of political action.

It is important to recognise that the Fund's rightful conduct has transformed in large part due to changes within the world economy since the 1970s. Certainly, the Fund today is dealing with an international political economy that is radically different from when it came into existence in 1945. Particularly important here is the Fund's 'silent revolution', from the late 1970s to the late 1980s, which entailed a change from dealing primarily with system management for Western industrialised states to dealing with crisis management for developing states (Boughton, 2001). This process was in large part a consequence of changing practices in the world economy, especially the increased role of private capital following the collapse of the Bretton Woods system and, in the 1980s, the rapid rise of financial disintermediation and securitisation. These processes, most prominent in the US, led to a rapid expansion of global debt within the international financial order and a clear move away from traditional bank lending (Seabrooke, 2001). Designed to deal with the management of national finances in a bank-driven credit system within a fixed exchange rate monetary system, this essentially left the Fund in an environment where developed states no longer needed Fund credit, and where developing states have had increased access to private capital markets.

Importantly, these changes in the world economy left the Fund dealing with enormous currency and liquidity crises with a comparatively much reduced funding base (Bordo and James, 2000). As a consequence, during the 1980s and 1990s, the Fund's role became that of a crisis manager, especially in Latin America and Eastern Europe (Pauly, 1997, 125-126). Given such changes, the Fund has also had to seek financial support from private 'supplementary financiers' who can provide capital for loans, but who require increased loan conditions (Gould, 2003). Furthermore, the financing of the Fund's own administrative expenses dramatically changed between 1980 and 2000, with 'creditor' member states reducing their contribution from 72 to 29 per cent of 
required financing, while 'debtor' states have increased their contribution from 28 to 71 per cent (Woods and Lombardi, 2006, 498).

As a consequence of the above dynamics, in the 1990s, the Fund found itself with an increased clientele who had either not substantially grown economically following Fund reform programmes, or were so crippled by external debt to make the prospect of economic reform exceedingly difficult. As a consequence it developed, with the World Bank, the Heavily Indebted Poor Countries initiative in 1996 and, following the Asian crisis, an independent review of the Enhanced Structural Adjustment Facility (ESAF) found that there was a clear lack of ownership, protection of the poor, and problems related to the division of labour among international organisations (namely the World Bank, see Vetterlein, 2006b, chapter 3). In response to these criticisms, the Fund developed, with the World Bank, 'poverty reduction strategy papers', which have also led to the development of the Poverty Reduction and Growth Facility (PRGF) that places stress on social development, poverty alleviation, and managing social risk (see also Broome, 2006; Vetterlein, 2006b). The PRGF itself has created internal dissent, with some staff claiming that it was 'simply not a legitimate part of the Fund's mandate to become directly involved in issues of poverty and economic growth' (Bird, 2001, 830). These changes have led to further criticisms concerning 'mission creep' - that the Fund's practices extend far beyond its rightful conduct and provide it with a new realm of political action in which it has little accountability (Woods, 2001).

The Fund's rightful conduct and realm of political action can also be viewed by how it designs economic reform programmes and their success. Indeed, most of the work on the Fund's problems, including its waning legitimacy, concentrates on reform programme failures. Earlier work here pointed to how the Fund's structural adjustment packages of the 1980s created negative outcomes (Bienen and Gersovitz, 1985), while more recent literature stresses how loan conditionality has become too homogeneous and insensitive to differences within borrowing states (notably Stiglitz, 2002). Here, the Fund is commonly seen as pursuing 'neoliberal' economic reforms that come with an extremely high social cost (Taylor, 2004).

The body of evidence on the Fund's success in the implementation of reform programmes is extensive. Scholars have demonstrated that economic growth during a loan programme is more likely to drop rather than increase (Przeworski and Vreeland, 2000), and that there are often lower growth rates after the loan period. Others have pointed to how Fund programmes are strongly associated with heightened income inequality (Garuda, 2000). On compliance with the Fund's policy conditions, it has also been suggested that, even when conditions are met, the wheels fall off afterwards (Evrensel, 2002).

The Fund's reform programme failures have led it increasingly to rely on pressure to produce positive results. While loan conditionality is the most 
obvious aspect here, an important change is the Fund's new discourse on the need for borrowing member states to publicly demonstrate 'ownership' and 'transparency' (Best, 2005). Even the Fund's formation of the Independent Evaluation Office (IEO) in 2001 was an explicit recognition of the Fund's postAsian financial crisis need to deal with rightful membership and rightful conduct problems by scrutinising itself, or 'leading by example' on transparency and accountability (Independent Evaluation Office, 2003b). This move can be seen as an institutional change to reconfigure its identity, role, and purpose to address its international crisis of legitimacy. It also recognises the extent of the Fund's realm of political action, as well as an attempt to reconfigure what it considers as its social constituency of legitimation. I return to this point below.

\section{Legitimacy Gaps and Associational Templates}

To conceptualise how the problems associated with the Fund's international crisis of legitimacy relate to the process of legitimation, it may be useful to consider a 'legitimacy gap'. Here, the claims to legitimacy made by the Fund are conferred or rejected by the expressive practices of those being governed, with the result widening or narrowing the gap between claims and acts. The power relationships, both direct and diffuse (Barnett and Duvall, 2005), that inform conferral or rejection relate to concerns of rightful membership, rightful conduct, the realm of political action, and the social constituency of legitimation discussed above. To be more precise, a legitimacy gap is understood as the space between claims to the fairness and rightfulness of policy actions by those who seek to govern, and the conferral of these claims through belief-driven acts of policy implementation by those being governed. ${ }^{3}$

Figure 1 expresses a legitimacy gap diagrammatically by borrowing from Graham Bird's work on the Fund's 'conditionality Laffer curve' (2003, 122). In the diagram, the line OX represents the optimal view often ascribed to the Fund - that as it increases the stringency of loan conditions, the likelihood of reform programme success will also increase. It also reflects the more recent view that requesting and requiring governments in borrowing states to declare their 'ownership' of reform policies will boost reform programme success. The line OX therefore represents the Fund's claim to the legitimacy of policy reforms. The OX line also fits with the conventional wisdom on how the Fund operates: that borrowers wouldn't reform their economies in 'IMF Friendly' ways without loan conditions being imposed (Vreeland, 2003b, 337). A number of conditions, marked on the diagram at B, will be seen as standard and, as James Vreeland has discussed, are often desired by borrowing states because they are in line with their own economic policy objectives (2003a, 56-57). But this holds true only up to a point, indicated by A, as when conditions are too 


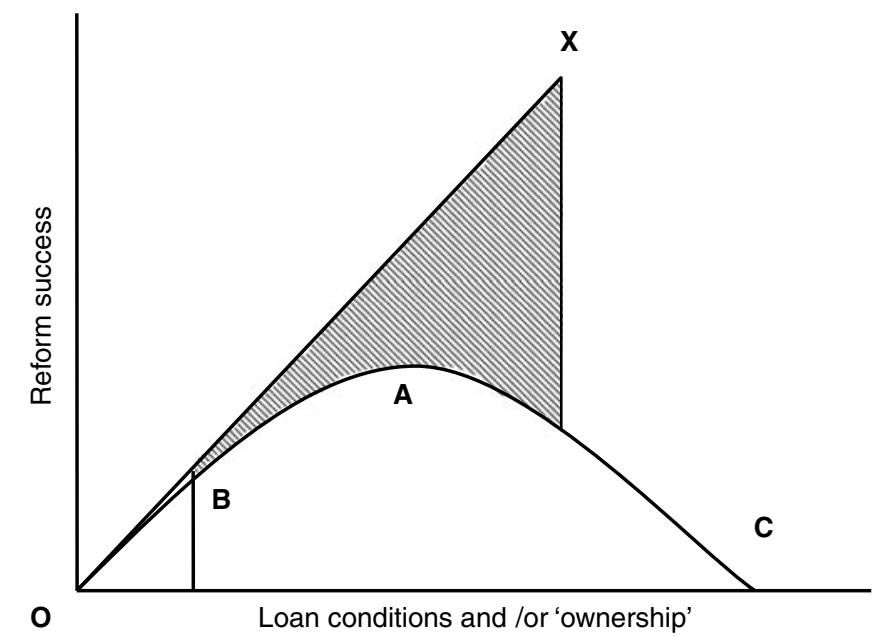

Figure 1 Reform programme feasibility curve with legitimacy gap.

stringent reform programme success diminishes. Any claims to the appropriateness of reform programme advice from B onwards require strong legitimacy claims from the Fund.

In Figure 1, the curve OC reflects acts taken by the borrowing states in response to legitimacy claims made by the Fund. The failure to successfully implement reform programmes may be seen as a technical or financial failure, and this may indeed be the case, but the Fund's own rhetoric in recent years suggests that 'political will' is a key problem. This view is that despite loan conditions and declarations of 'ownership', the governments of borrowing member states do not have the political will to push through reforms. Accordingly, the shaded area in the figure represents the legitimacy gap. Within this space we can find conflict over rightful membership and rightful conduct, as well as the consequence of the Fund's failure to match its social constituency of legitimation with its realm of political action. Narrowing the gap requires a resolution to the crisis (discussed below), or, in the diagram, bending both the OX and OC lines to be more closely coordinated.

One way to do this is to provide more customised policy advice. However, there are clear limits to providing customised advice given that the Fund's resources are limited (more now than ever), and that highly customised advice invites allegations of favouritism. As such, excessive customisation would violate rightful membership and rightful conduct, particularly the principle that all member states should be treated equally. Of course, as discussed above, the bulk of criticism against the Fund is that it provides excessively 
homogeneous 'one-size-fits-all' policies to all member states. To work our way through the two extremes of complete customisation and excessive homogeneity, my reading of Fund archival documents on taxation reform between 1965 and 2000, as well as interviews with Fund staff (Seabrooke, 2006d), suggests that the Fund did, and can, use what I refer to as an associational template (cf. Xu, 2005; see also Broome and Seabrooke, 2006).

The purpose of templates is to legitimise claims to economic reform on the grounds that they are appropriate for a state in a region with $x$ characteristics, or belonging to a group of states with $x$ characteristics. So while the Fund undoubtedly has a range of policies it considers to be 'IMF Friendly' for all states, templates permit partial customisation of policies. South Korea's tax revenue system, for example, is positively compared with its Asian neighbours until 1996 when the state joined the Organisation for Economic Co-operation and Development (OECD) (Seabrooke, 2006b). In the past, the use of templates permitted the Fund to claim the legitimacy of rightful membership, by treating all members equally, as well as to make a legitimacy claim to rightful conduct by framing policy advice within a more localised frame. Given the use of associational templates, we may think of how the Fund could encourage its 'IMF Friendly' policies in borrowing states through the process depicted in Figure 2.

Here, the 'IMF Friendly' policy mix represents an independent variable, the use of an associational template the first conditional variable, with a second conditional variable concerning how the borrowing state then translates the 'IMF Friendly' policy into a domestic context where it is recombined with elements that lend the policy domestic legitimacy (Jacobsson et al., 2004; Broome, 2006). If both conditions are achieved, then policy implementation may be possible.

My reading of Fund documents (Executive Board minutes, loan arrangements, and staff reports) for a range of states suggests that the use of templates has probably waned over time. This may be attributed to internal dynamics within the Fund: namely an internal change in power dynamics in the determination of reform policies from the area desks (the Fund has departments for Africa, Asia and Pacific, Europe, the Middle East and Central Asia, and the Western Hemisphere) to the policy departments, such as

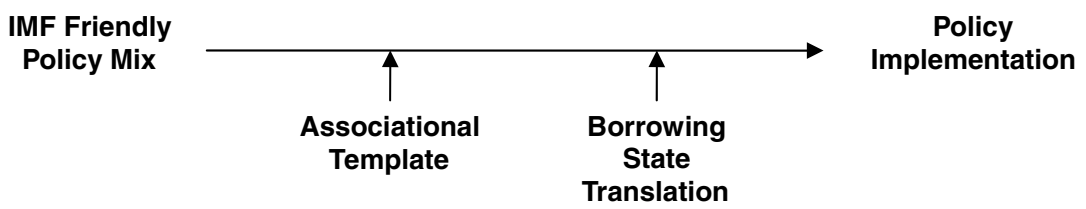

Figure 2 How the IMF influences member states. 
the Fiscal Affairs Department for taxation and, most importantly, the Policy Development and Review Department. Fund staff interviewed during August 2005 suggested that the policy departments had increased their prominence in providing 'world's best practice' policy design for reform programmes, while area desks were more concerned with assessing what policies can be implemented. ${ }^{4}$ Such internal changes within the Fund have created 'pathologies' (Barnett and Finnemore, 2004) that deepen violations of rightful membership and rightful conduct, while also expanding the Fund's realm of political action without accordant attempts to redefine its social constituency of legitimation. Rather, the tactic up until the turn of the century was to rely on technical expertise to support claims to legitimacy, as well as to increase loan conditions.

The problems with this strategy, specifically in relation to the Asian financial crisis, have been recognised by the Fund. In recognising its own international crisis of legitimacy, Montek Ahluwalia, the Director of the Fund's IEO argued in 2003 that:

Overloading programs with multiple conditions, exemplified by the Indonesia program of January 1998, diffuses attention making it difficult to ensure implementation of what is really critical. It is also often resented as being excessively intrusive, especially in a democratic environment (Ahluwalia, 2003, 7).

Beyond overloading reform programmes with conditions, staff within the Fund increasingly recognise that loan programme rules associated with rightful membership and rightful conduct are out of sync with its realm of political action and, by association, its social constituency of legitimation. For example, during interviews with staff from the Fiscal Affairs Department, staff accepted that a reform programme for a significant tax systems change, such as the introduction of a Value Added Tax, requires ten years. ${ }^{5}$ Now, the maximum single loan programme with strong economic reforms (such as the ESAF and now PRGF) is three years. The Fund is therefore operating on a longer policy horizon than its formal rules permit. This change exemplifies the need for the Fund to formally realign its institutional structure and means of engaging in a dialogue with its borrowing states, rather than relying on a discourse of 'ownership' and a technocratic approach to 'world's best practice' as the key elements of its claims to legitimacy.

\section{The Fund's Existing Strategies for Crisis Resolution}

How can the Fund disentangle itself from its current international crisis of legitimacy? This article suggests that the recent criticism launched at the Fund following its misdiagnosis of the Asian financial crisis, its own 
questioning of its role and purpose, and unfair voting structure do not in themselves sufficiently explain its international crisis of legitimacy. Rather, longer-term violations of rightful membership and rightful conduct, as well as a mismatch between the Fund's realm of political action and its social constituency of legitimation, provide a better conceptual handle on how a legitimacy gap has become an international crisis. It is these foreground and background changes that have widened the gap between what the Fund can claim has legitimacy in reforming states, and what its member states will actually act upon.

It should be noted that the Fund is actively seeking ways of resolving its international crisis by how it claims legitimacy. The Fund plans to implement institutional changes to address rightful membership problems, as well as, more controversially, to dramatically widen its social constituency of legitimation.

First of all, on rightful membership the recent stress on how the Fund can resolve its international crisis of legitimacy has been upon a change in voting shares. As discussed above, the current distribution of votes is heavily biased towards Western states, especially the US, and grossly under-represents emerging market and developing states, particularly those in East Asia (Rapkin and Strand, 2006). The Fund is now actively pursuing an agenda to reshuffle the distribution of voting rights. In September 2005, in a forum on reforming the Fund, Rodrigo de Rato stated:

The Fund's ability to persuade our members to adopt wise policies depends not only on the quality of our analysis but also on the Fund's perceived legitimacy. And our legitimacy suffers if we do not adequately represent countries of growing economic importance. This means, in particular, increases in voting power for some of the emerging-market economies, especially in Asia (de Rato, 2006, 131).

This was a significant acknowledgement of the Fund's legitimacy crisis, which has been followed up by the Fund's Board of Governors' September 2006 approval of a voting reform programme, to be implemented over a two-year period, that provides clear increases in voting rights for China, South Korea, Mexico, and Turkey, as well as opening up discussions for the doubling of basic voting rights to give more power to the Fund's poorest member states. ${ }^{6}$ The change in voting rights is expected to come at a cost to European states rather than to the US (Truman, 2006, 529-530). Discussions on how the Fund can resolve its legitimacy crisis have also converged, like that on international financial architecture more broadly (Seabrooke, 2006a, chapter 7), on the inclusion of the G-20 as a new 'steering committee' for the Fund (Truman, 2006, 530-531). In addition to these reforms, there are growing calls for the Fund to adopt 'double majority' voting requirements, so that both 85 per cent of votes in total, as well as a 60 per cent majority of members, would be 
required for a special decision (Woods and Lombardi, 2006, 495). Such a change would broaden consultation among member states and, with it, further deliberation.

The Fund's reforms to its rightful membership should be congratulated and may well assist it in making its 'foreground' claims to legitimacy more persuasive. It does little, however, to address the Fund's 'background' legitimation problems concerning how its realm of political action and its changing perception of what should constitute its social constituency of legitimation match up. For example, recent debate has included the use of 'naming and shaming' techniques for misbehaving states (Truman, 2006, 531), akin to how the OECD has 'shamed' tax havens (Sharman, 2006). Such a strategy violates rightful membership and rightful conduct. It would also provide a clear demonstration that the Fund is interested in imposing a 'standard of civilisation' on its member states (Best, 2006).

Also of concern is the Fund's plans to explicitly broaden its social constituency of legitimation in a manner that violates rightful membership. We return once more to recent comments by Rodrigo de Rato on the need to improve the communication and the transmission of Fund advice:

[T] here are countries where the Fund gives advice that is not followed. Sometimes this is because of disagreement on the analysis of the issue. These are cases where we obviously need a serious, engaged, dialogue with the member on the nature of the problem and how to fix it. But there are also plenty of cases where there is agreement on the analysis but reluctance to act on that analysis for political reasons. In these cases, I would like the Fund to be more forthright in making the case for the policies we support, including to the public. In globalized democracies, public opinion can be changed by persuasive arguments, and changes in public opinion can change the positions of policymakers ... where we help generate public support for good policies, we can go further and do a service to our member governments by making the case for reform in a clear and forthright way (de Rato, 2006, 132).

The Fund therefore seeks to bolster its legitimacy claim by appealing to the public within member states. This is a logical extension of the Fund's recent insistence that borrowing member states demonstrate their 'ownership' of economic reform programmes. However, if the Fund wishes to 'lock-in' political will through direct appeal to the public, this is a clear change in what it considers its social constituency of legitimation. While we may, on the face of it, applaud the Fund's willingness to engage 'civil society', the above strategy is fraught with problems (Thirkell-White, 2004). First and foremost, the Fund's role is not to appeal to citizens within states to take on Fund policies. The Fund's member states join on the principle of sovereign non-interference, so the 
notion that citizens should receive information to pressurise their governments to adopt Fund policies is a violation of principles of rightful membership and rightful conduct. Second, the Fund is poorly resourced to provide direct appeals to citizens within states, not the least because it has less than a third of the staff of the World Bank. Third, if the Fund's key means of claiming legitimacy is to rely on the production of 'world's best practice' economic policy, one wonders how it will get its message across to ordinary citizens.

\section{Conclusion: Alternative Proposals to Resolve the Fund's Legitimacy Crisis}

An alternative and, to my mind, superior strategy is for the Fund to improve deliberation with its member states, especially borrowing member states, rather than engaging in new forms of public diplomacy for which it is not equipped or authorised. One way to do so is for the Fund to place greater stress on the need for area desks to customise policies for borrowing states, rather than relying on 'world's best practice' engineered by the Fund's policy departments to immediately take precedence. The Fund could explicitly use associational templates to bolster their legitimacy claims and increase the likelihood that member states will confer their consent for appropriate economic reform policies and act upon them. Regional or like-group (context sensitive) meetings could include not only member states but also other groups, such as trade unions (Vreeland, 2003a), NGOs, and private economic interests (who the Fund is consulting in private during standard surveillance missions in many member states). The Fund has already constructed institutions that could be used for this purpose, such as the Regional Office for Asia and the Pacific, so forging explicitly regional-level meetings could be presented as institutional evolution rather than as a radical reform. Importantly, such meetings would permit the Fund to ask like-states what they want in economic policy, without embarrassing or shaming governments. Certainly, the BIS has been successful in promoting regional fora to foster a normative consensus (Seabrooke, 2006c). Fostering deliberation among regional or like-groups would allow the Fund to use its expertise and put its institutional memory to good use. Furthermore, as Woods and Lombardi's (2006) work points out, internal decision making within the Fund already operates around regional and like-groups. An explicit strategy of customised deliberation, in association with voting reform, would therefore provide one means of bringing closer together foreground legitimacy claims related to rightful membership and background legitimacy claims related to its social constituency of legitimation.

On how the Fund and its member states act, the pressing need for the Fund is institutional reform that recognises that it is under-funded and therefore pressed to rely on an odd combination of moral suasion and technocratic 
expertise. To alleviate this problem, Graham Bird has suggested that the Fund should be much more engaged with international private capital markets to raise more of its own funding $(2001,841)$. A better-funded Fund, alongside a new mandate that recognises its expanded policy practice, would allow it to strengthen its foreground claims to rightful conduct. If this can be achieved then the Fund's realm of political action can be clearly marked rather than the Fund engaging in ever-increasing 'mission-creep'. If all of the above could be achieved then bringing foreground and background claims in line with acts is more likely and the legitimacy gap could be narrowed.

Importantly, and while the prospect of the above happening is far from clear, the Fund must protect its member states' sovereignty for its legitimacy claims to have a chance of being conferred and acted upon. Deliberation between the Fund and states is the only means of bringing together the foreground and background aspects described above. The Fund does have sufficient autonomy from its key member states to transform how it deals with its member states, if not complete institutional reform due to its voting structure. Its 'organisational slippage' can be reversed not with an insistence on transparency and accountability in its member states, but by being more flexible in how it designs and implements its policies (Babb, 2003; Best, 2005). While it may sound old fashioned, the key means to coordinate and foster deliberation within an international organisation is through the sovereign state. Resolving the Fund's international crisis of legitimacy requires it to avoid an odd combination of economic dogma and civil society engagement, and, instead, use its autonomy to adapt founding political principles to new economic realities.

\section{Notes}

1 This article was drafted while a visitor at the Norwegian Institute of International Affairs (NUPI), Oslo. It was then revised during a visit to the Center for the Advanced Study of the Behavioral Sciences (CASBS), Stanford University. My thanks go to all of the participants in this symposium, as well as to Mick Cox, for their feedback on earlier versions of this piece at both the Canberra 2005 and Bellagio 2006 workshops. My thanks also go to Jacquie Best, Anna Persson, Ole Jacob Sending, Shogo Suzuki, and Antje Vetterlein for their conversations and comments on earlier drafts. My special thanks go to André Broome for his extensive comments on earlier drafts. My thanks also go to the archivists in the International Monetary Fund Archives, Washington, DC, especially Madonna Gaudette, Premela Isaacs, and Jean Marcouyeux.

2 The hunch on templates is drawn from a broader study of the Fund and tax policy advice to 20 states between 1965 and 2000. In the broader study, the states are: Indonesia, South Korea, the Philippines, Thailand, Romania, Yugoslavia, Turkey, Argentina, Bolivia, Chile, Ecuador, Mexico, Morocco, Egypt, Pakistan, Sri Lanka, Cote d'Ivoire, Ghana, Senegal, and Zambia. A companion study on small open economies is also under development (see Broome and Seabrooke, 2006). On the Asian states alone, see Seabrooke 2006b. The broader study is under development. 
3 Of course it is necessary to specify, case by case, when the failure to implement policy is not due to a lack of belief but due to technical or financial capacities. While in the past the Fund concentrated on building administrative, technical, and financial capacities, its recent shift to stressing 'political will' and 'transparency' in member states points to a legitimation problem rather than to a 'know-how' or resources problem.

4 As commented to me in an interview with a Fund staff member in Washington, DC, August 2005.

5 Interview with staff member of Fiscal Affairs Department, IMF, in Washington, DC, August 2005.

6 'IMF Board of Governors Approves Quota and Related Governance Reforms', IMF Press Release No. 6/205, September 18, 2006, www.imf.org/external/np/sec/pr/2006/pr06205.htm.

\section{References}

Ahluwalia, M.S. (2003) 'IMF Operations and Democratic Governance: Some Issues', public address to the General Assembly of the Club de Madrid, November 1, www.clubmadrid.org.

Babb, S. (2003) 'The IMF in Sociological Perspective: A Tale of Organizational Slippage', Studies in International Comparative Development 38(2): 3-27.

Barnett, M. and Duvall, R. (2005) 'Power in International Politics', International Organization 59(1): 39-75.

Barnett, M. and Finnemore, M. (2004) Rules for the World, Ithaca: Cornell University Press.

Best, J. (2005) The Limits of Transparency, Ithaca: Cornell University Press.

Best, J. (2006) 'Civilizing through Transparency: The International Monetary Fund', in B. Bowden and L. Seabrooke (eds.) Global Standards of Market Civilization, London: Routledge/RIPE Global Political Economy Series, 134-145.

Bienen, H.S. and Gersovitz, M. (1985) 'Economic Stabilization, Conditionality, and Political Stability', International Organization 39(4): 729-754.

Bird, G. (2001) 'A Suitable Case for Treatment? Understanding the Ongoing Debate about the IMF', Third World Quarterly 22(5): 823-848.

Bird, G. (2003) The IMF and the Future, London: Routledge.

Bordo, M.D. and James, H. (2000) 'The International Monetary Fund: Its Present Role in Historical Perspective', NBER Working Papers No. 7724, Cambridge, Mass.: National Bureau of Economic Research.

Boughton, J.M. (2001) Silent Revolution, Washington, DC: IMF.

Boughton, J.M. (2003) 'Who's in Charge? Ownership and Conditionality in IMF-Supported Programs', IMF Working Paper WP/03/191, Washington, DC: IMF.

Bowden, B. and Seabrooke, L. (eds.) (2006) Global Standards of Market Civilization, London: Routledge/RIPE Series in Global Political Economy.

Broome, A. (2006) 'Civilizing Labor Markets: The World Bank in Central Asia', in B. Bowden and L. Seabrooke (eds.) Global Standards of Market Civilization, London: Routledge/RIPE Global Political Economy Series, 119-130.

Broome, A. and Seabrooke, L. (2006) 'Seeing Like the IMF: Institutional Change in Small Open Economies', unpublished manuscript, International Center for Business and Politics, Copenhagen Business School, May.

Campbell, J.L. and Pedersen, O.K. (1996) 'The Evolutionary Nature of Revolutionary Change in Postcommunist Europe', in J.L. Campbell and O.K. Pedersen (eds.) Legacies of Change, New York: Aldine de Guyter, 207-251.

Clark, I. (2005) Legitimacy in International Society, Oxford: Oxford University Press.

de Rato, R. (2006) 'The IMF View on IMF Reform', in E.M. Truman (ed.) Reforming the IMF for the 21st Century, Washington, DC: Institute for International Economics, 127-132. 
Evrensel, A.Y. (2002) 'Effectiveness of IMF-supported Stabilization Programs in Developing Countries', Journal of International Money and Finance 21(5): 565-587.

Garuda, G. (2000) 'The Distributional Effects of IMF Programs: A Cross-Country Analysis', World Development 28(6): 1031-1051.

Gould, E.R. (2003) 'Money Talks: Supplementary Financiers and International Monetary Fund Conditionality', International Organization 57(3): 551-586.

Hall, R.B. (2003) 'The Discursive Demolition of the Asian Development Model', International Studies Quarterly 47(1): 71-99.

Hobson, J.M. and Seabrooke, L. (eds.) (2007) Everyday Politics of the World Economy, Cambridge: Cambridge University Press.

Independent Evaluation Office (2003a) Fiscal Adjustment in IMF-Supported Programs, Washington, DC: IMF.

Independent Evaluation Office (2003b) The IMF and Recent Capital Account Crises, Washington, DC: IMF.

Jacobsson, B., Lægreid, P. and Pedersen, O.K. (2004) Europeanization and Transnational States, London: Routledge.

Leaver, R. and Seabrooke, L. (2000) 'Can the IMF be Reformed?', in W. Bello, N. Bullard and K. Malhortra (eds.) Global Finance, London: Zed Press, 25-35.

Momani, B. (2004) 'American Politicization of the International Monetary Fund', Review of International Political Economy 11(5): 880-904.

Pauly, L.W. (1997) Who Elected the Bankers?, Ithaca: Cornell University Press.

Przeworski, A. and Vreeland, J.R. (2000) 'The Effect of IMF Programs on Economic Growth', Journal of Development Economics 62(2): 385-421.

Rapkin, D. and Strand, J. (1997) 'The United States and Japan in the Bretton Woods Institutions: Sharing or Contesting Leadership?', International Journal 52(20): 265-296.

Rapkin, D.P. and Strand, J.R. (2006) 'Reforming the IMF's Weighted Voting System', The World Economy 29(3): 305-324.

Seabrooke, L. (2001) US Power in International Finance, Basingstoke: Palgrave Macmillan.

Seabrooke, L. (2006a) The Social Sources of Financial Power, Ithaca: Cornell University Press.

Seabrooke, L. (2006b) 'Legitimacy Gaps in Global Standards of Market Civilization: The International Monetary Fund and Tax Reform', paper presented at the Annual Conference of the International Studies Association, San Diego, March 22-25.

Seabrooke, L. (2006c) 'The Bank for International Settlements', New Political Economy 11(1): 141-149.

Seabrooke, L. (2006d) 'Legitimacy Gaps in Global Economic Governance: The International Monetary Fund and Tax Reform', book manuscript in preparation, International Center for Business and Politics, Copenhagen Business School, October.

Seabrooke, L. (2007) 'Everyday Legitimacy and International Financial Orders: The Social Sources of Imperialism and Hegemony in Global Finance', New Political Economy 12(1), forthcoming.

Sharman, J.C. (2006) Havens in a Storm, Ithaca: Cornell University Press.

Stiglitz, J. (2002) Globalization and its Discontents, London: Penguin.

Stone, R. (2002) Lending Credibility, Princeton: Princeton University Press.

Taylor, I. (2004) 'Hegemony, Neoliberal "Good Governance" and the International Monetary Fund: A Gramscian Perspective', in M. Bøås and D. McNeill (eds.) Global Institutions and Development, London: Routledge, 124-136.

Thacker, S. (1999) 'The High Politics of IMF Lending', World Politics 52(1): 38-75.

Thirkell-White, B. (2004) 'The International Monetary Fund and Civil Society', New Political Economy 9(2): 251-270.

Truman, E.M. (2006) 'An IMF Reform Package', in E.M. Truman (ed.) Reforming the IMF for the 21st Century, Washington, DC: Institute for International Economics, 527-540. 
Vetterlein, A. (2006a) 'Change in International Organizations: Innovation or Adaptation?', in D. Stone and C. Wright (eds.) The World Bank and Governance, Routledge: London, 125-144.

Vetterlein, A (2006b) 'International Organizations and Poverty', unpublished book manuscript, Department of Social Policy and Social Work, Oxford University.

Vreeland, J.R. (2003a) The IMF and Economic Development, Cambridge: Cambridge University Press.

Vreeland, J.R. (2003b) 'Why Do Governments and the IMF Enter into Agreements? Statistically Selected Cases', International Political Science Review 24(3): 321-343.

Wade, R. and Veneroso, F. (1998) 'The Asian Crisis: The High Debt Model versus the Wall StreetTreasury-IMF Complex', New Left Review 228: 3-23.

Woods, N. (2001) 'Making the IMF and the World Bank More Accountable', International Affairs 77(1): 83-100.

Woods, N. and Lombardi, D. (2006) 'Uneven Patterns of Governance: How Developing Countries are Represented in the IMF', Review of International Political Economy 13(3): 480-515.

Xu, Y-C. (2005) 'Models, Templates and Currents: The World Bank and Electricity Reform', Review of International Political Economy 12(4): 647-673. 